\title{
Characterization of the acute inflammatory response in the hybrid tambacu (Piaractus mesopotamicus male $\times$ Colossoma macropomum female) (Osteichthyes)
}

\author{
Martins, ML. ${ }^{\mathrm{a}}$, Myiazaki, DMY. ${ }^{\mathrm{b}}$,Tavares-Dias, M. ${ }^{\mathrm{c}}$, Fenerick Jr., J. , \\ Onaka, EM. ${ }^{\mathrm{e}}$, Bozzo, FR. ${ }^{\mathrm{f}}$, Fujimoto, RY. ${ }^{\mathrm{g}}$ and Moraes, FR. ${ }^{\mathrm{d}, \mathrm{f}}$ \\ aLaboratório AQUOS-Sanidade de Organismos Aquáticos, Departamento de Aqüicultura, \\ Centro de Ciências Agrárias - CCA, Universidade Federal de Santa Catarina - UFCS, \\ Rod. Admar Gonzaga, 1346, CEP 88040-900, Florianópolis, SC, Brazil \\ bPoli-Nutri Alimentos, Rua Américo Vespúcio, 99/109, CEP 06273-070, Osasco, SP, Brazil \\ 'Departamento de Ciências Fisiológicas, Instituto de Ciências Biológicas - ICB, \\ Universidade Federal do Amazonas - UFAM, Manaus, AM, Brazil \\ ${ }^{\mathrm{d} C e n t r o ~ d e ~ A q u ̈ i c u l t u r a, ~ U n i v e r s i d a d e ~ E s t a d u a l ~ P a u l i s t a ~-~ U N E S P, ~}$ \\ Via Prof. Paulo Donato Castellane, Km 3, CEP 14870-000, Jaboticabal, SP, Brazil

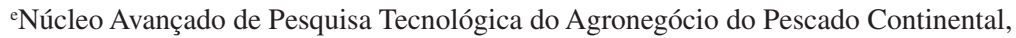 \\ Instituto de Pesca, Rod. Washington Luiz, Km 445, CEP 15025-970 São José do Rio Preto, SP, Brazil

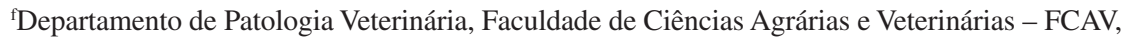 \\ Universidade Estadual Paulista - UNESP, Via Prof. Paulo Donato Castellane, Km 3, CEP 14870-000, Jaboticabal, SP, Brazil \\ 'Núcleo de Estudos Costeiros, Universidade Federal do Pará - UFPA, \\ Al. Leandro Ribeiro, s/n, Aldeia, CEP 8600-000, Bragança, PA, Brazil \\ *e-mail: mlaterca@cca.ufsc.br
}

Received March 6, 2008 - Accepted July 15, 2008 - Distributed August 31, 2009

(With 4 figures)

\begin{abstract}
This work evaluated the acute inflammatory response induced by injections of $0.5 \mathrm{~mL}$ saline solution (control), $500 \mu \mathrm{g}$ carrageenin and $0.5 \mathrm{~mL}$ thioglycollate $3 \%$ in the swim bladder of juvenile tambacu hybrid. Fish were distributed in three treatments, three replications and acclimated for a period of 10 days before assay. The cell characterization from the inflammatory exudate was performed in Giemsa and PAS stained smears. Carrageenin, injected in fish, showed an increase on the total number of cells in the inflammatory exudate when compared to saline and thioglycollate injected. Whereas, for carrageenin-injected fish, the percentage of thrombocyte was higher than thioglycollate. On the other hand, granulocyte percentage in thioglycollate-injected fish was higher than the ones injected using carrageenin. Carrageenin provoked the highest migration of macrophage to the inflammatory site. The PAS method confirmed the presence of three types of granulocytes: eosinophilic granular cell (EGC) type 1 with the characteristics of a special granulocytic cell commonly found in the circulating blood; EGC type 2 shorter than the last one and neutrophil. This study contributes to a better understanding of the inflammatory response and infectious processes in native fish.
\end{abstract}

Keywords: fish, hybrid tambacu, inflammation, exudate, carrageenin, thioglycollate.

\section{Caracterização da resposta inflamatória aguda no híbrido tambacu (Piaractus mesopotamicus macho $\times$ Colossoma macropomum fêmea) (Osteichthyes)}

\footnotetext{
Resumo

Este estudo avaliou a resposta inflamatória aguda induzida por injeções de $0,5 \mathrm{~mL}$ de solução salina (controle), $500 \mu \mathrm{g}$ de carragenina e $0,5 \mathrm{~mL}$ de tioglicolato a $3 \%$ na bexiga natatória de juvenis do híbrido tambacu. Os peixes foram distribuídos em três tratamentos, três repetições e aclimatados durante 10 dias antes do ensaio. A caracterização das células do exsudato inflamatório foi feita após coloração com Giemsa e PAS. Peixes injetados com carragenina apresentaram maior número de células no exsudato inflamatório do que com salina e tioglicolato. A porcentagem de trombócitos no exsudato foi maior nos injetados com carragenina quando comparada com a dos injetados com tioglicolato. Por outro lado, o percentual de granulócitos foi maior em animais injetados com tioglicolato do que em animais injetados com carragenina. A carragenina provocou maior migração de macrófagos para o foco inflamatório. O método de PAS
} 
confirmou a presença de três tipos de granulócitos: célula granular eosinofílica (CGE) tipo 1 com as características da célula granulocítica especial encontrada no sangue, CGE tipo 2, menor do que esta última, e de neutrófilos. Este estudo contribui para o melhor entendimento da resposta inflamatória e dos processos infecciosos em peixes nativos.

Palavras-chave: peixe, híbrido tambacu, inflamação, exsudato, carragenina, tioglicolato.

\section{Introduction}

The first observation of fish inflammation was related by Mesnill (1895) with injections of Bacillus anthracis in the visceral cavity. Later, the inflammatory response was evaluated by ink injection (Ellis et al., 1976), complete Freund's adjuvant and Staphylococcus aureus (Finn and Nielsen, 1971), carrageenin (Timur et al., 1977), Escherichia coli lipopolysaccharide (LPS), complete Freund's adjuvant, turpentine and carrageenin (White et al., 1981), Vibrio alginolyticus (MacArthur et al., 1984), liquid paraffin (Suzuki, 1986), Edwardsiella ictaluri LPS (Saeed and Plumb, 1986), Pseudomonas alcaligenes and Aeromonas punctata (Siwicki and Studnicka, 1987), Aeromonas salmonicida (Reite and Evensen, 1994), LPS (Brunetti et al., 1994), Freund's adjuvant and squalene (Jenkins and Klesius, 1998), microcystin (Vajcová et al., 1998), Escherichia coli (Matsuyama et al., 1999), peptidoglican (Kono and Sakai, 2001), beta-glucan of Saccharomyces cerevisiae and Salmonella typhimurium LPS (Paulsen et al., 2001) and Mycobacterium marinum (Gauthier et al., 2003). In these studies, the inflammation was characterized by showing macrophages, leucocytes, fibroblasts and fibroplasia.

In Brazil, Matushima and Mariano (1996) injected carrageenin in the swim bladder of tilapia (Oreochromis niloticus Linnaeus, 1758) and demonstrated an inflammatory reaction composed of vascular congestion, thrombocytes, rare granulocytes and oedema. Inflammation induced by carrageenin was also reported in the swim bladder of pacu (Piaractus mesopotamicus Holmberg, 1887) with the presence of macrophages and mainly thrombocytes (Martins et al., 2006). Nevertheless, Martins et al. (2001a) proved carrageenin to be an important inflammatory agent causing haematological changes in the hybrid tambacu. Except for the studies of Martins et al. (2006), little is known about the inflammatory response and infectious processes in Brazilian native fish.

This study evaluated the inflammatory response induced by injections of saline, carrageenin and thioglycollate in the swim bladder of the hybrid tambacu. The characterization of cells involved in the inflammatory response was performed by staining with Giemsa and PAS. This assay contributes to a better understanding of cell migration in the inflammatory and infectious processes of Brazilian fish.

\section{Material and Methods}

\subsection{Fish maintenance}

This work was developed at the Pathology Laboratory of Aquatic Organisms, Aquaculture Centre, UNESP,
Jaboticabal, SP, Brazil. Fish of $153.44 \pm 70.14$ g mean weight and $19.79 \pm 3.47 \mathrm{~cm}$ total length were distributed in 12 aquaria with constant water flow, six animals in each and three replicates. Fish were acclimated for 10 days before assay and daily fed with a commercial diet. During this period water temperature range was $28.09 \pm 1.31{ }^{\circ} \mathrm{C} ; \mathrm{pH} 7.64 \pm 0.67$, electric conductivity $146.46 \pm 66.75 \mu \mathrm{S} . \mathrm{cm}^{-1}$, dissolved oxygen $4.51 \pm$ $1.21 \mathrm{mg} . \mathrm{L}^{-1}$ and alkalinity $87.09 \pm 3.25 \mathrm{mg} . \mathrm{L}^{-1}$.

\subsection{Injection and collection of exudate cells}

The fish were anaesthetized by immersion in benzocaine solution $\left(1 \mathrm{~g} .10 \mathrm{~L}^{-1}\right)$ and injected with $500 \mu \mathrm{g}$ carrageenin (Marine Colloids) dissolved in $0.5 \mathrm{~mL}$ sterile saline solution, $0.5 \mathrm{~mL}$ thioglycollate $3 \%$ and $0.5 \mathrm{~mL}$ sterile saline solution (control). After injection, the fish were maintained in the aquaria for 6 hours until the sacrifice. The interior of the swim bladder was washed with complete phosphate buffered saline containing $0.01 \mathrm{~mL}$ EDTA $5 \%$ and cell suspensions were centrifuged at $150 \times$ gravity for 10 minutes before staining. The total number of cells was determined with a haemocytometer. Smears were made on microscope slides, air-dried, fixed and stained with Giemsa or periodic acid of Schiff (PAS). From the smears the percentages of macrophages, lymphocytes, granulocytes and thrombocytes were determined and cells measured in an image analyzer Videoplan Kontron Elektronic Zeiss.

\subsection{Cytochemistry}

This analysis was made by demonstrating glycogen using the method of PAS (McManus, 1946) to blood cells and modified for exudate cells as follows: after being fixed in Gendre solution $(85 \mathrm{~mL}$ picric acid saturated in ethyl alcohol 96\%, $10 \mathrm{~mL}$ of formalin $40 \%, 5 \mathrm{~mL}$ acetic acid, the smears were refrigerated for 5 minutes and immersed in periodic acid $1 \%$ for 20 minutes, Schiff for 55 minutes, washed three times in sulphured water for 3 minutes, washed quickly in distilled water, stained by Harris haematoxylin for 5 minutes and washed in water. To control the specificity of the method, the smears were treated with saliva amylase, in a wet chamber $37{ }^{\circ} \mathrm{C}$ for 1 hour, washed in water for 10 minutes and had applied to them the PAS method according to Lison (1960).

\subsection{Statistical analysis}

The comparison of averages was performed by the Tukey test at $5 \%$ probability and the percentage of differential counting of exudate cells were transformed in $\operatorname{arc} \sin (\sqrt{\mathrm{P}}+0.5)($ Snedecor and Cochran, 1989). 


\section{Results}

Carrageenin and thioglycollate, injected in fish, showed the highest accumulation of inflammatory cells in the exudate of the swim bladder characterized by a yellowish colour and gelatinous consistency. In saline injected (control) the exudate formation was not observed. Carrageenin-injected animals showed significant increase of total cell number in the exudate when compared to saline and thioglycollate. Nevertheless, the total number of cells in fish injected with saline and thioglycollate did not differ between them (Figure 1).

Differential counting of exudate cells showed a predominance of thrombocytes followed by macrophages and lymphocytes (Figure 2). Carrageenin, injected in fish, showed higher thrombocyte percentage than those injected with thioglycollate. On the other hand, the percentage of granulocyte was higher after injection with

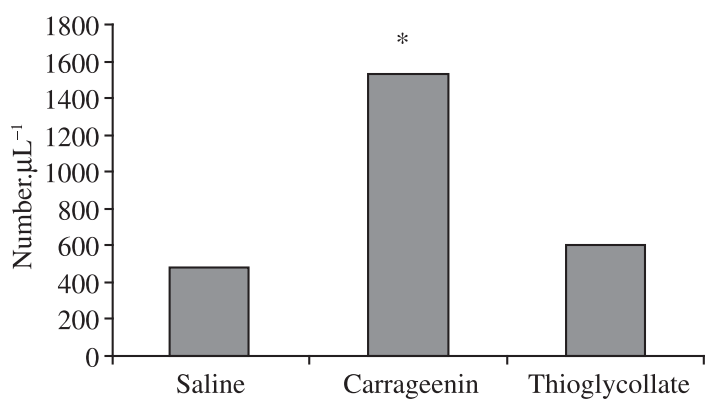

Figure 1. Total cell number from the swim bladder exudate of the hybrid tambacu 6 hours after injection $(* \mathrm{P}<0.01)$.
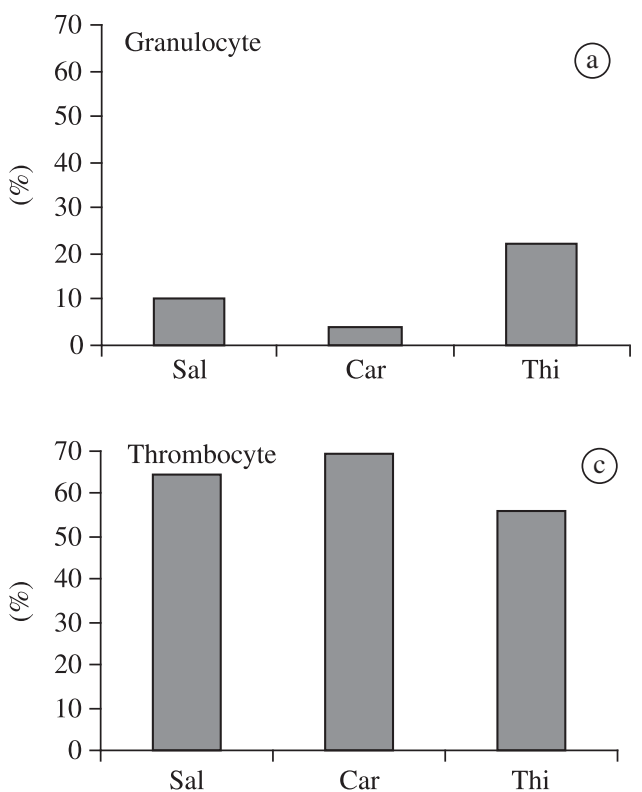

thioglycollate than with carrageenin and saline. The injections of saline and thioglycollate were also responsible for an increase in the lymphocyte percentage while carrageenin caused the highest migration of macrophage to the inflammatory site.

\subsection{Description of the exudate cells in the hybrid tambacu (Figures 3-4)}

Eosinophilic granular cell type 1: the largest cell found in the exudate measuring $16.1 \pm 4.4 \mu \mathrm{m}$ diameter, similar to the special granulocytic cell observed in the circulating blood. Its nucleus was eccentric, round to elliptic in shape and of dark colour. Cytoplasm filled with whitish refringent granules when observed with a light microscope. The method with specificity control to saliva amylase stained positively with PAS. In this case, the granules were uniformly arranged and stained intensively with PAS suggesting the presence of neutral glycoproteins.

Eosinophilic granular cell type 2: smaller than EGC 1 this cell measured $9.4 \pm 0.6 \mu \mathrm{m}$ diameter. Eccentric, round to elliptic dark nucleus and cytoplasm showing weak refringency when compared to EGC 1. PAS showed the same characteristics of EGC 1.

Neutrophil: their presence was rare in the smear with intermediate size between EGC and lymphocyte, $12.6 \pm 1.9 \mu \mathrm{m}$ diameter. Nucleus round to bilobed or horseshoe shaped, and not well-delimited. It presented an acidophilic feature and sometimes with inclusions that were not stained. With a light microscope the granule refringency was not observed in their cytoplasm. PAS showed the presence of glycogen granules after
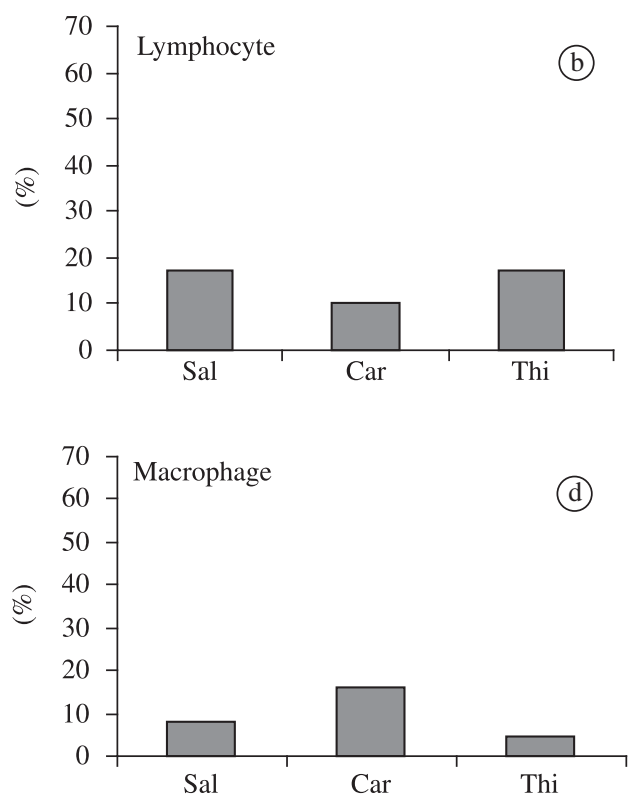

Figure 2. Mean values of the differential counting of cells from the swim bladder exudate of the hybrid tambacu 6 hours after injection with saline (Sal), carrageenin (Car) and thioglycollate (Thi). Different letters indicate significant difference $(\mathrm{P}<0.01)$ between the injected substances. 


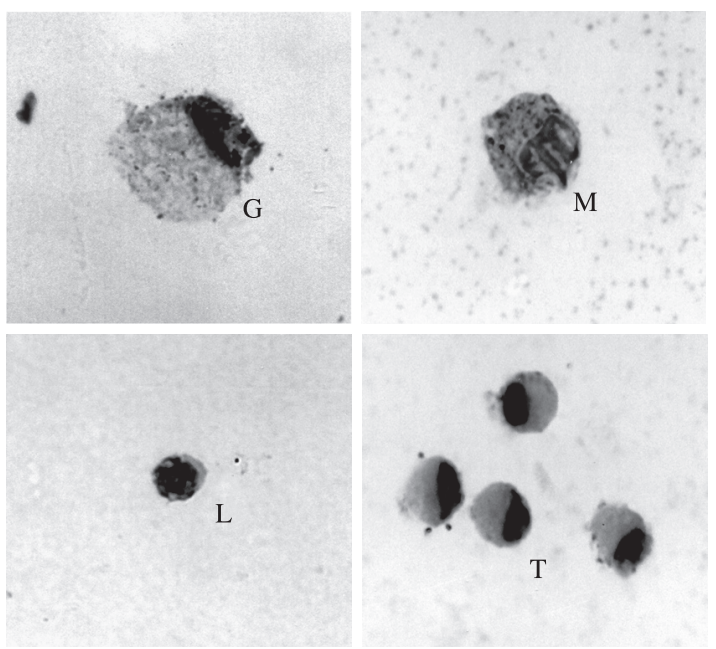

Figure 3. Exudate cells from the swim bladder of the hybrid tambacu 6 hours after injection stained by Giemsa. EGC type $1(\mathrm{G})$; macrophage $(\mathrm{M})$; lymphocyte (L) and trombocytes $(\mathrm{T}) . \times 1,801$.
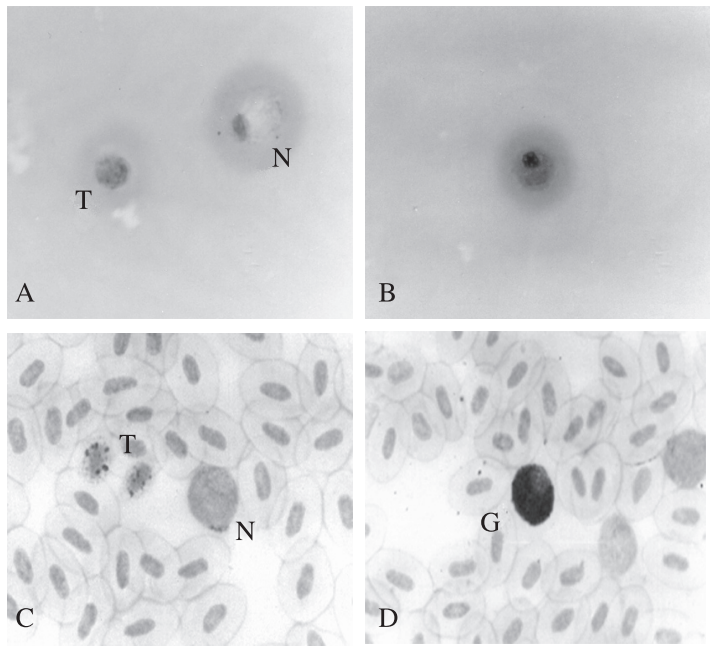

Figure 4. Comparison among cells from the exudate of the swim bladder of the hybrid tambacu and related cells from the circulating blood. A) - thrombocyte (T); EGC type 2 (N) and B - EGC type 1 stained by PAS. C-D: Cells from the circulating blood of the hybrid tambacu stained by PAS. Note dark granules in thrombocyte $(\mathrm{C})$ and intense colour of EGC (D). $\times 1,801$.

digestion with saliva amylase. However, these granules were poorly stained with PAS when compared to EGC. From these characteristics it was possible to confirm this cell as a neutrophil, especially when compared to those found in the circulating blood.

Thrombocyte: smaller than macrophage and granulocyte, $7.6 \pm 0.6 \mu \mathrm{m}$ diameter, eccentric dark nucleus round to elongated shape. Its cytoplasm shows basophilic to slightly greyish staining, lacking granules and vacuoles. With the smear confection its cytoplasm may be found spread to a unique direction for several times. PAS method with specificity control by saliva amylase showed positive reaction with glycogen granules distributed in its cytoplasm concentrated in some area with more or less colour intensity.

Lymphocyte: the smallest cell found in the exudate, $5.8 \pm 0.8 \mu \mathrm{m}$ diameter, round to slightly oval, dark nucleus of dense appearance occupying the whole of the cell. The little cytoplasm that can be seen presents basophilic staining and irregular like lymphocyte from the circulating blood.

Macrophage: cell of intermediate size between lymphocyte and thrombocyte, $6.5 \pm 0.6 \mu \mathrm{m}$ diameter, nucleus strongly basophilic showing coloured areas. Its cytoplasm is slightly basophilic with irregular areas and sometimes the presence of phagocyted material can be seen.

\section{Discussion}

Macroscopically the exudate showed a yellowish colour and gelatinous consistency in the carrageenin and thioglycollate injected in fish, corroborating the findings of Martins et al. (2006) in P. mesopotamicus. On the other hand, macroscopically, it seems that tambacu showed lower response when compared to P. mesopotamicus studied by the last author.

Total number of cells from the inflammatory exudate of the hybrid tambacu was lower than that observed in P. mesopotamicus by Martins et al. (2006) after carrageenin injection. Differential counting of exudate cells showed the highest values of thrombocytes in saline injected tambacu when compared to P. mesopotamicus (Martins et al., 2006). But, concerning lymphocyte, tambacu showed values from 10 to 20 times greater than the ones observed in P. mesopotamicus. Therefore, the great percentage of macrophage here related after carrageenin injection was according to Martins et al. (2006). Not only lymphocyte but also thrombocyte migrated to the inflammatory focus in tambacu after injection with the substances. This was contrary to the answers previously obtained in P. mesopotamicus when the presence of these cells was not up to $2.4 \%$ in the exudate smear. In the present work, saline and thioglycollate injections recruited a great number of lymphocyte and granulocyte. Following this view, this was an important difference when comparing tambacu and P. mesopotamicus studied by Martins et al. (2006). Although the total number of cells found in the tambacu exudates had been reduced, several types of cells other than those found in $P$. mesopotamicus were observed.

The predominance of thrombocyte followed by a low number of macrophage in the swim bladder of carrageenin injected in fish supported the results obtained by Matushima and Mariano (1996) in O. niloticus. Contrarily, $15.9 \%$ of recovered tambacu macrophages were different from that author. The resident population of cells in the cavity of Oncorhynchus mykiss Walbaum, 1792 showed 
33 to $39 \%$ of macrophage, 46 to $56 \%$ of lymphocyte, 1.3 to $2.2 \%$ of granulocyte and rarely thrombocyte (Afonso et al., 1997). As related by Martins et al. (2006), in native fish, P. mesopotamicus, this trial did not observe resident cells in the hybrid tambacu. Consequently, it was necessary to stimulate the swim bladder to obtain response. In contrast, Flores Quintana (2002) observed 43\% macrophage and $56 \%$ lymphocyte in the visceral cavity of unstimulated $P$. mesopotamicus. Another reason for this difference in the resident cell is that the swim bladder is an organ separated from organs in the visceral cavity. However, carrageenin injection increases the macrophage population in the swim bladder of tambacu and P. mesopotamicus. The choice of swim bladder for this assay was due to the advantage of low influence of contamination by other organs during the application of irritant as emphasized by Chen et al. (1998).

Low percentage of macrophage observed in this assay corroborated the findings of Ellis et al. (1976) after intraperitoneal injection with ink in Pleuronectes platessa Linnaeus, 1758. However, the injection with turpentine can cause inflammation in mammals but White et al. (1981) did not observe the same response in P. platessa. These authors verified that LPS injection in that fish increased the concentration of C-reactive protein indicating inflammatory response as well as that related in this assay with carrageenin and thioglycollate. Carrageenin injection caused the highest inflammatory reaction in the tropical fish tambacu six hours after whereas White et al. (1981) related the same response in P. platessa four days after carrageenin injection. By supporting the above statement, the hypotheses that fish from a tropical climate respond more rapidly to inflammation and wound healing than those maintained in a temperate climate must be emphasized (Finn and Nielsen, 1971). LPS and E. coli intraperitoneally injected in P. platessa provoked a migration three times superior than the normal leucocyte number, as related by MacArthur et al. (1984). Martins et al. (2006) reported the highest accumulation of cells in the inflammatory focus of carrageenin injected P. mesopotamicus. As in the present assay, carrageenin and thioglycollate injected in tambacu showed more inflammatory response than in control fish. Despite the fact that saline injection provoked migration of inflammatory cells to the swim bladder, the response was significantly reduced in comparison to carrageenin injected in fish. On the other hand, thioglycollate was not responsible for a great accumulation of inflammatory cells in the exudate when counted in haemocytometer, being sometimes similar to saline injection.

Jenkins and Klesius (1998) related more macrophage migration in Freund's adjuvant and squalene injected in Ictalurus punctatus Rafinesque, 1818 than the ones that received thioglycollate. Contrarily, this assay related thioglycollate as a stimulator of thrombocyte, granulocyte and lymphocyte migration to the inflammatory site. From this point of view, Afonso et al. (1998) verified an increase in macrophages and neutrophil migration in the visceral cav- ity of incomplete Freund's adjuvant and Yersinia ruckeri killed by formalin injected in $O$. mykiss. The present result was according to the findings of Matsuyama et al. (1999) who injected $E$. coli killed by formalin in the swim bladder of $O$. niloticus. The authors also observed macrophage and lymphocyte migration to the inflammatory focus.

Chadzinska et al. (2000) reported increased number of total leucocytes after injection with thioglycollate in the peritoneal cavity of Carassius auratus Linnaeus, 1758 in relation to non-injected fish. Consequently, this work has demonstrated the low action of thioglycollate in tambacu that can be seen by the similar values of saline injected. Suzuki and Hibiya (1988) reported infiltration of neutrophils in the orbital of carp one day after injection with arabic gum. In this assay, neutrophill migration was more pronounced by saline and thioglycollate injections which were also corroborated by the findings of Do Vale et al. (2002). Finally, these results might explain the migration of cells involved in the inflammatory response caused by parasites in native fish (Martins et al., 2000, 2001b).

The PAS analysis confirmed the presence of three types of granulocytes in the exudate. Eosinophilic granular cells (EGC) type 1 and 2 were differentiated by their size and intensity of staining. These cells from the swim bladder exudate showed the same characteristics of the special granulocytic cell found in the circulating blood. These characters were confirmed after saliva amylase digestion. As a result of its granule characteristics in the granulocytes, the presence of glycoproteins was observed (Carvalho, 2002). The presence of neutrophils was rare but also confirmed by PAS. Supporting this view, this is the first report on the presence of EGC in the exudate of the tambacu hybrid. Until then, in the studies with P. mesopotamicus (Martins et al., 2006) the presence of these cells had not been verified. The morphology and staining intensity of granulocytes found in tambacu were similar to EGC described by Matsuyama and Iida (1999) in the swim bladder exudate of $O$. niloticus. According to Carvalho (2002) the presence of thrombocytes by morphology and staining was confirmed in this assay. In this case, the cytoplasm showed positive reaction determined by the red colour of the granules especially in the peripheral region. In addition, glycogen granules in the thrombocyte cytoplasm were distributed in all the cytoplasm but in variable concentration. Such as observed in this work, thrombocyte morphology from the exudate was slightly different from that observed in the circulating blood, as also supported by Matushima and Mariano (1996).

Further studies with cytochemistry of the exudate cells in Brazilian fish must be encouraged because of its importance in the defense organism system. Moreover, other fish species must be explored to compare the exudate composition and intensity of the inflammatory response. This work demonstrated that the cells in exsudate of tambacu hybrid are different from those described for P. mesopotamicus (Martins et al., 2006). In conclusion, future studies with vitamins and immunostimulants sup- 
plementation might be performed to evaluate the intensity of the inflammatory response in Brazilian fish and its relation with fish health status.

Acknowledgements - The authors thank FAPESP (00/12566-9) and $\mathrm{CNPq}$ (520211/00-6, 502177/04-7, 301072/07-8) for financial support. Dr. Euclides Braga Malheiros and Dr. Áureo Evangelista Santana (FCAV, UNESP, Jaboticabal, SP) respectively, for statistical analysis and photomicrographys.

\section{References}

AFONSO, A., ELLIS, AE. and SILVA, M., 1997. The leucocyte population of the unstimulate peritoneal cavity of rainbow trout (Oncorhynchus mykiss). Fish and Shellfish Immunology, vol. 7, no. 1, p. 335-348.

AFONSO, A., LOUSADA, S., SILVA, J., ELLIS, AE. and SILVA, MT., 1998. Neutrophil and macrophage responses to inflammation in the peritoneal cavity of rainbow trout Oncorhynchus mykiss. A light and electron microscopic cytochemical study. Diseases of Aquatic Organism, vol. 34 , no. 1, p. 27-37.

BRUNETTI, L., PREZIOSI, P., RAGAZZONI, E. and VACCA, M., 1994. Effects of lipopolysaccharide on hypothalamic-pituitary-adrenal axis in vitro. Life Sciences, vol. 54, no. 10, p. 165-171.

CARVALHO, VAL., 2002. Aspectos morfológicos e citoquímicos dos glóbulos sangüíneos e ultraestruturais de trombócitos e granulócitos do surubim cachara, Pseudoplatystoma fasciatum (Linnaeus, 1766) Osteichthyes, Siluriformes. São Paulo: Universidade Federal de São Paulo - UNIFESP. 101 p. Dissertação de Mestrado.

CHADZINSKA, M., SCISLOWSKA-CZARNECKA, A. and PLYTYCZ, B., 2000. Inhibitory effects of morphine on some inflammation-related parameters in the goldfish Carassius auratus L. Fish and Shellfish Immunology, vol. 10, no. 6, p. 531-542.

CHEN, SC., YOSHIDA, T., ADAMS, A., THOMPSON, KD. and RICHARDS, RH., 1998. Non-specific immune response of Nile tilapia, Oreochromis nilotica, to the extracellular products of Mycobacterium spp and to various adjuvants. Journal of Fish Diseases, vol. 21, no. 1, p. $39-46$.

Do VALE, A., AFONSO, A. and SILVA, MT., 2002. The professional phagocytes of sea bass (Dicentrarchus labrax L.): cytochemical characteristics of neutrophils and macrophages in the normal and inflamed peritoneal cavity. Fish and Shellfish Immunology, vol. 13, no. 3, p. 183-198.

ELlis, AE., MUNROE, ALS. and ROBERTS, RJ., 1976. Defence mechanisms in fish. Journal of Fish Bioliology, vol. 8, no.1, p. 67-78.

FINN, JP. and NIELSEN, NO., 1971. The inflammatory response of rainbow trout. Journal of Fish Biology, vol. 3, no. 4, p. 463-478.

FLORES QUINTANA, C., 2002. Respostas locais e sistêmicas por endotoxinas em Piaractus mesopotamicus (Holmberg, 1887) tratados com cromo. Jaboticabal: Universidade Estadual Paulista - UNESP. 67 p. Tese de Doutorado.

GAUTHIER, DT., RHODES, MW., VOGELBEIN, WK., KATOR, H. and OTTINGER, CA., 2003. Experimental mycobacteriosis in striped bass Morone saxatilis. Diseases of Aquatic Organisms, vol. 54, no. 1, p. $105-117$.

JENKINS, JA. and KLESIUS, PH., 1998. Elicitation of macrophages from the peritoneal cavity of channel catfish. Journal of Aquatic Animal Health, vol. 10, no. 1, p. 69-74.

KONO, T. and SAKAI, M., 2001. The analysis of expressed genes in the kidney of japanese flounder, Paralichthys olivaceus, injected with immunostimulants peptidoglycan. Fish and Shellfish Immunology, vol. 11 , no. 4 , p. $357-366$.

LISON, L., 1960. Lipides et lipoproteines. In LISON, L. (Ed.). Histochemie et cytochimie animals: principes et méthods. Paris: GauthirVillars 2. p. 449-530.

MacARTHUR, JI., FLETCHER, TC., PIRIE, BJS., DAVIDSON, RJL. and THOMSON, AW., 1984. Peritoneal inflammatory cells in plaice, Pleuronectes platessa L.: effects of stress and endotoxin. Journal of Fish Biology, vol. 25, no. 1, p. 69-81.
McMANUS, JFA., 1946. Histological demonstration of mucin after periodic acid. Nature, vol. 158, August, p. 202-202.

MARTINS, ML., FUJIMOTO, RY., MORAES, FR., ANDRADE, PM., NASCIMENTO, AA. and MALHEIROS, EB., 2000. Descrição e prevalência de larvas de Thynnascaris SP. Dollfus, 1933 (Nematoda: Anisakidae) em Plagioscion squamosissimus Heckel, 1840 proveniente do reservatório de Volta Grande, Estado de Minas Gerais, Brasil. Revista Brasileira de Biologia (Brazilian Journal of Biology), vol. 60, no. 3, p. 519-526.

MARTINS, ML., ONAKA, EM., TAVARES-DIAS, M., BOZZO, FR. and MALHEIROS, EB., 2001a. Características hematológicas do híbrido tambacu, seis e 24 horas após a injeção de substâncias irritantes na bexiga natatória. Revista de Ictiologia, vol. 9, no. 1-2, p. 25-31.

MARTINS, ML., MORAES, FR., FUJIMOTO, RY., ONAKA, EM. and QUINTANA, CIF., 2001b. Prevalence and histopathology of Neoechinorhynchus curemai Noronha, 1973 (Acantocephala: Neoechinorhynchidae) in Prochilodus lineatus Valenciennes, 1836 from Volta Grande Reservoir, MG, Brazil. Brazilian Journal of Biology, vol. 61, no. 3, p. 517-522.

MARTINS, ML., MORAES, FR., FUJIMOTO, RY., ONAKA, EM., BOZZO, FR. and MORAES, JRE., 2006. Carrageenin induced inflammation in Piaractus mesopotamicus (Osteichthyes: Characidae) cultured in Brazil. Boletim do Instituto de Pesca, vol. 32, no. 1, p. 31-39.

MATSUYAMA, T., IIDA, T. and ENDO, M., 1999. Isolation of inflammatory macrophages from swim bladder of tilapia. Fish Pathology, vol. 34 , no. 2 , p. 83-84

MATSUYAMA, T. and IIDA, T., 1999. Degranulation of eosinophilic granular cells with posible involvement in neutrophil migration to site of inflammation in tilapia. Developmental and Comparative Immunology, vol. 23, no. 6, p. 451-457.

MATUSHIMA, ER. and MARIANO, M., 1996. Kinetics of the inflammatory reaction induced by carrageenin in the swimbladder of Oreochromis niloticus (Nile tilapia). Brazilian Journal of Veterinary Research and Animal Science, vol. 33, no. 1, p. 5-10.

MESNILL, F., 1895. Sur le mode des resistance des vertebrades inferieures aux invasions microfiennes. Annals Institute Pasteur, vol. 2, p. 301-311.

PAULSEN, SM., ENGSTAD, RE. and ROBERTSEN, B., 2001. Enhanced lysozyme production in Atlantic salmon (Salmo salar L.) macrophages treated with yeast $\beta$-glucan and bacterial lipopolysacharide. Fish and Shellfish Immunology, vol. 11, no. 1, p. 23-37.

REITE, OB. and EVENSEN, O., 1994. Mast cells in the swimbladder of Atlantic salmon Salmo salar: histochemistry and responses to compound 48/80 and formalin-inactivated Aeromonas salmonicida. Diseases of Aquatic Organisms, vol. 20, no. 2, p. 95-100.

SAEED, MO. and PLUMB, JA., 1986. Immune response of channel catfish to lipopolysaccharide and whole cell Edwardsiella ictaluri vaccines. Diseases of Aquatic Organisms, vol. 2, no. 1, p. 21-25.

SIWICKI, A. and STUDNICKA, M., 1987. The phagocytes ability of neutrophils and serum lysozyme activity in experimentally infected carp, Cyprinus carpio L. Journal of Fish Biology, vol. 31, (supl. A), p. 57-60.

SNEDECOR, GW. and COCHRAN, G., 1989. Statistical methods. Ames: Iowa State University Press, 503 p.

SUZUKI, K., 1986. Morphological and phagocytic characteristics of peritoneal exudate cells in tilapia, Oreochromis niloticus (Trewavas), and carp, Cyprinus carpio L. Journal of Fish Biology, vol. 29, no. 3, p. 349-364.

SUZUKI, Y. and HIBIYA, T., 1988. Dynamics of leucocytic inflammatory responses in carp. Fish Pathology, vol. 23, no. 3, p. 179-184.

TIMUR, G., ROBERTS, RJ. and McQUEEN, A., 1977. Carrageenin granuloma in the place (Pleuronectes platessa) a histopathological study of chronic inflammation in a teleost fish. Journal of Comparative Pathology, vol. 87, p. 83-87.

VAJCOVÁ, V., NAVRÁTIL, S. and PALÍKOVÁ, M., 1998. The effect of intraperitoneally applied pure microcystin LR on haematological, biochemical and morphological indices of silvercarp (Hypophthalmichthys molitrix Val.). Acta Veterinaria Brno, vol. 67, p. 281-287.

WHITE, A., FLETCHER, TC., PEPYS, MB. and BALDO, BA., 1981. The effect of inflammatory agents on C-reactive protein and serum amyloid P-component levels in plaice (Pleuronectes platessa $\mathrm{L}$.) serum. Comparative Biochemistry and Physiology, vol. 69C, no. 2, p. 325-329. 